Article Review

\title{
Kandungan Gizi Bulu Babi Diadema setosum
}

\author{
Yusran H. Sadu* \\ * Jurusan Manajemen Sumber Daya Perairan, Fakultas Perikanan dan IImu Kelautan, Universitas \\ Negeri Gorontalo. Email: yusransadu99@gmail.com
}

\section{Introduction}

Wilayah perairan Indonesia memiliki sumberdaya hayati yang sangat tinggi di dunia. Salah satu sumberdaya hayati yang memiliki nilai ekonomis dan produktif yang sangat besar adalah bulu babi (sea urchin) (Nane, 2019a). Bulu babi merupakan salah satu sumberdaya hayati laut yang mempunyai prospek untuk dikembangkan. Bulu babi mempunyai peranan yang penting dari segi ekologis maupun ekonomis (Calderon dkk, 2007 dalam Erlyta, 2015; Nane, 2019c). Bulu babi di manfaatkan sebagai bahan makanan yaitu dengan mengambil gonadnya (Vimono, 2007 dalam Lawi, dkk, 2019; Nane, 2019d). Di Indonesia bulu babi dikonsumsi dalam keadaan segar (mentah) atau dalam keadaan dimasak (Nane, 2019d, Tupan dan Silaban, 2017). Bulu babi dimanfaatkan masyarakat pesisir sebagai bahan makanan (Junaidi, 2013).

Bulu babi termasuk dalam anggota filum Echinodermata ( dari bahasa yunani yang artinya kulit berduri). Anggota dari filum Echinodermata terdiri dari beberapa kelas, salah satunya yaitu kelas Echinoidae yang merupakan hewan laut berbentuk bulat dan memiliki duri pada kulitnya yang dapat digerakan (Wulandewi dkk, 2015). Bulu babi merupakan organisme yang bersifat omnivore yang memangsa atau memakan makroalga dan beberapa jenis koloni karang (Ristanto,2018 dan Suryanti ,2014). Menurut Yusron, (2013).

Morfologi bulu babi (Echinoidea) memiliki bentuk tubuh yang bulat dan memiliki duri dipermukaan tubuhnya. Hewan ini juga biasanya di temukan berada di padang lamun dan banyak bersembunyi di celah-celah karang yang ada diperairan (Susilo, 2017; Nane dkk., 
2020). Bulu babi merupakan kelompok hewan lunak yang bercangkang dan termasuk dalam filum Echinodermata serta tidak memiliki tulang belkang (Avertebrata) (Rajab dkk, 2010). Menurut Nane, (2013) bulu babi memiliki bentuk tubuh yang khas yaitu menyerupai bola atau bundar pipih, seluruh permukaan tubuhnya ditutupi duri, mulutnya terletak dibagian bawah dan anusnya menghadap ke atas. Menurut Huda (2016) secara umum bulu babi dikelompokan menjadi dua spesies yaitu regularia dan irregularia. Bulu babi jenis regularia memiliki ciri bentuk tubuh bulat, mulut terletak pada bagian oral dan anus terletak pada bagian ujung aboral, sedangkan bulu babi jenis irregularia memiliki ciri bentuk tubuh bulat pipih, bagian anus terletak di tepi oral atau aboral.

Echinodermata merupakan salah satu komponen utama dari keanekaragaman hayati laut yang memainkan peran penting dalam fungsi ekosistem perairan (Supono dkk, 2014). Echinodermat disebut sabagai salah satu spesies kunci bagi komunitas terumbu karang dikarenakan Echinodermata adalah salah satu pengendali populasi karoalga yang terdapat di ekosistem terumbu karang dan menyeimbangkan kembali ruang tempat terumbu karang tersebut (Raghunathan, 2012 dan Ayyagari, 2014) Secara umum Echinodermata lebih banyak dijumpai pada perairan yang jernih dan tenang (Radjab dkk, 2014). Suryanti dan A'in (2013) menyatakan bahwa bulu babi banyak ditemukan pada ekosistem terumbu karang terutama jenis D. Setosum, karena kelimpahan dari populasi spesies tersebut penting bagi terumbu karang sebagai penyeimbang. Keberadaan bulu babi D. Setosum pada ekosistem terumbu karang memberikan pengaruh yang signifikan terhadap keseimbangan ekologi (Thamrin dkk, 2011).

Penyebaran bulu babi di pengaruhi oleh kondisi habitat dan lingkungan. Bulu babi menyebar karena adanya kondisi lingkungan yang sesuai dengan habitatnya, bulu babi tumbuh dan menyebar di daerah terumbu karang, lamun, hutan mangrove dan ganggang (Irianto dkk, 2016). Menurut Nazar, (2017) bahwa penyebaran suatu organisme kedaerah tertentu, penyebaran echinoidea sangat tergantung pada factor habitat dan makanan yang terdapat di sekeliling biota tersebut dan paling utama pada ekosistem terumbu karang. Yudasmara, (2013) mengatakan bahwa umumnya setiap jenis bulu babi memiliki sebaran habitat yang spesifik. Di Indonesia, Malaysia, Filipina, dan Australia Utara ada sekitar 316 
jenis bulu babi, sedangkan di perairan Indonesia ada sekitar 84 jenis bulu babi yang berasal dari 21 filum dan 48 genus (Akerina, 2015). Pada umumnya setiap jenis bulu babi tersebar mulai dari daerah intertidal yang dangkal sampai ke laut dalam. Bulu babi menghuni ekosistem terumbu karang dan padang lamun serta menyukai subtrat di padang lamun yang merupakan campuran daripasir dan pecahan karang (Aziz, 1994 dalam Mistiasih, 2013).

Bulu babi diketahui mengandung gizi yang tinggi di antaranya nilai protein dengan berat basah antara 7,04-8,20\% (nilai protein dengan berat kering antara 51,80-57,80), nilai lemak dengan berat basah antara 1,14-1,35\% (nilai lemak dengan berat kering antara 8,53-9,36\%), nilai kadar air berkisar antara $84,17 \%-87,82 \%$ dan nilai kadar abu antara 1,81-1,86\% (Chasanah \& Andamari,2011), namun komposisi gizi yang terkandung pada bulu babi berbeda-beda tergantung dari jenisn, ukuran, umur, dan lingkungan hidupnya (Silaban dan Srimariana, 2013). Menurut Kato dan Schroeter, (2010) gonat pada bulu babi memiliki kandungan gizi yang baik. Gomat bulu babi mengandung protein, lipid dan glikogen, selain itu gonad bulu babi juga mengandumg kalsium, fos- for, vitamin A, B, B2, B12, asam nikotinik, asam pantotenik, asam folik dan karotin. Karena itu, bulu babi di beberapa negara maju. Gonadnya sangat diminati. Sayangnya, pemanfaatan dan penangkapan bulu babi di Wakatobi, Indonesia saat ini sedang mengalami overfishing (Nane, 2019b; Nane dan Paramata, 2020)

Biota laut memiliki keanekaragaman tinggi yang dapat dimanfaatkan untuk kehidupan. Biota laut ini sangat berpotensi sebagai sumber senyawa antitumor, diantaranya adalah berasal dari filum Echinodermta (Mangindaan dan Margareth, 2013). Salah satu biota laut yang berpotensi dijadikan sebagai bahan obat-obatan adalah bulu babi dari kelas Echinoidae. Senyawa aktif yang terkandung dalam bulu babi memiliki aktivitas antibakteri terhadap staphilococcus aureus dan Eschericha, coli (Akerina, dkk 2015). Aktifitas antibakteri ditemukan pada bagian tubuh yang berada pada green sea urchin dengan menggunakan bakteri uji. Hasil ini menunjukan bahwa filum echinodermata yang salah satunya bulu babi memiliki potensi sebagai antimikroba alami (Uma dan Parvathavarthini, 2010). 
Metabolit yang dihasilkan oleh bulu babi dapat dimanfaatkan dalam bidang pengobatan yang berpotensi sebagai antibiotik karena mengandung senyawa bioaktif (Abubakar dkk, 2012). Sebuah studi melaporkan adanya 43\% aktivitas antimikroba yang berasal dari 83 spesies dari filum Echinodermata yang tidak diidentifikasi yang diperoleh dari pantai barat daya California dan Teluk California yang menunjukan adanya aktivitas antimikroba, kemudian sebesar 58\% dari 36 speseis yang tidak diidentifikasi dari Laut Karibia juga menunjukkan adanya aktivitas antimikroba (Li et al,

2010). Para ahli menggunakan bulu babi sebagai organisme yang populer untuk mempelajari biologi

reproduksi, embriologi, toksikilogi, regulasi gen dan biologi evolusi. Cangkan dan gonad pada bulu babi diketahui memiliki nilai ekonomi yang tinggi.

\section{Conclusion}

Dari hasil pembahasan di atas dapat disimpulkan bahwah bulu babi (echinoidae) termasuk dalam filum echinodermata (dari bahasa yunani yang artinya kulit berduri). Bulu babi Bulu babi merupakan kelompok hewan lunak yang bercangkang dan tidak memiliki tulang belakang (Avertebrata). Bulu babi memiliki bentuk tubuh bulat atau bulat pipih,seluruh tubuhnya memiliki duri-duri yang digunakan untuk berjalan, mulutnya terletak dibagian bawah. Bulu babi memiliki peran penting bagi ekosistem laut terutama pada ekosistem lamun dan ekosistem terumbu karang. penyebaran bulu babi di pengaruhi oleh kondisi habitat dan lingkungan, bulu babi tumbuh dan menyebar di daerah terumbu karang, lamun, hutan mangrove dan ganggang. . Di Indonesia, Malaysia, Filipina, dan Australia Utara ada sekitar 316 jenis bulu babi. Penyebaran bulu babi di perairan Indonesia ada sekitar 84 jenis bulu babi yang berasal dari 21 filum dan 48 genus. Bulu babi merupakan organisme laut yang memiliki nilai ekonomis dan produktifitas yang sangat besar. Bulu babi dimanfaatkan sebagai bahan makanan. Di Indonesia bulu babi dikonsumsi dalam keadaan segar (mentah) atau dalam keadaan dimasak. 


\section{References}

Abubakar, Laila., Catherine Mwangi., Jacquiline Uku., dan Samuel Ndirangu. (2012). Antimicrobial Activity of various extracts of the sea urchin Tripneustes gratilla (Echinoidae). African Journal of Pharmacology and Therapeutics. 1(1), 19-23.

Akerina, Febrina Olivia., Tati Nurhayati., dan Ruddy Suwandy. (2015). Isolasi dan Karakteristik Senyawa Antibakteri Dari Bulu babi. JPHPI 2015, 18(1).

Akerina, F. O. (2015). Eksplorasi Senyawa Antimikroba dan Antioksidan dari Bulu Babi (Diadema setosum). [Skripsi, Institut Pertanian Bogor]

Aprilia, Hilda Ayu., Delianis Pringgenies., Ervia Yudiati. (2012). Uji Toksisitas Ekstark Kloroform Cangkang dan Duri Landak Laut (Diadema setosum) Terhadap Mortalitas Neuplius Artemia sp. Journal of Marine Research. 1(1), 75-8.

Ayyagari, A. and Kondamudi, R. B. (2014). Ecological Significance of theassociation bet ween stomopneustes variolaris (Echinoidae) and lumbrineris latreilli (polychaeta) from Visakhapatnam Coast India. Jurnal of Marine Biologi: India.

Chasana E, Andamari R. (2011). Komposisi Kimia, Profil Asam Aemak dan Asam Amino gonad Bulu Babi Tripneustes gratilla dan Salmanic sp dan Potensi Pengmbangannya. Di dalam prosiding seminar kelautan LIPI-UNHAS ke 1. Balitbang sumberdaya Laut, puslitbang Oseanologi-LIPI. 269-274.

Erlyta, A. (2015). Pola Distribusi Dan Kelimpahan Echinoidea Di Zona Intertidal Pantai Bama Taman Nasi Onal Baluran. Skripsi. Jurusan Biologi, Fakultas Matematika Dan IImu Pengetahuan Alam, Universitas Jember.

Hilda AP, Delanis dan Ervia.( 2012). 'Uji Toksisitas Ekstrak Kloroform Cangkang dan Duri Landak Laut (Diadema setosum) terhadap Mortalitas Nauplius Artemia sp', Jurnal of Marine Research, vol. 1, no. 1, hal. 75-83.

Huda, M. A. I. (2016) Keanekaragaman Jenis Echinodea Di Zona Intertidal Panati Jeding Taman Nasional Baluran.

Irianto, A., Jahidin, Sudarajat, H. W., (2016). Kelimpahan Bulu Babi (Echinoidea) Di Intertidal Perairan Pulau Liwutongkidi Kecamatan Siompu Kabupaten Buton Selatan. 
Junaidi Indra Z.( 2013). Komunitas Bulu Babi (Echinoidae di Pulau Cingkuak, Pulau Sikuai dan Pulau Setan Sumatera Barat, Proseiding semirata, Lampung: FMIP Universitas Lampung, 2013.

Lawi, Y. S. A., Sitepu, F. G., \& Dahlan, M. A. (2019). Nisbah Kelamin dan Ukuran Pertama Kali Matang Gonad Bulu Babi Trpneustes Gratilla (Linnaeus 1758) Pada Ekosistem Lamun Dan Ekosistem Berpasir Di Pulau Barrang Lompo Sulawesi Selatan. Octopus: Jurnal IImu Perikanan, 8(2), 15-20.

Li, C., Haug, T., Stensvag, K. (2010). Atimicrobial Peptides in Echinodrems. Invertebrate Survival Journal, 132-140.

Mangindaan, Remy E.P dan Margareth S. P. Lesnussa. 2013. Aktivitas Sitotoksis Dari Ekstrak Bintang Ular (Ophiomastix annulosa) Terhadap Perkembangan Awal Embrio Bulu babi (Tripneustes gratila) Jurnal Pesisir Laut Tropis, 3(1).

Nane, L. (2019a). Efisiensi Mesin Teknologi Sapurata Dalam Mengoptimalisasi Produksi Inovasi Pangan Kukure Di Pulau Barrang Lompo, Makassar. https://doi.org/10.31230/osf.io/q8spg

Nane, L. (2019b). Impact of overfishing on density and test-diameter size of the sea urchin Tripneustes gratilla at Wakatobi Archipelago, south-eastern Sulawesi, Indonesia. BioRxiv, 727271. https://www.biorxiv.org/content/10.1101/727271v1

Nane, L. (2019c). Sea Urchin Sustainability Studies Based on Dimension Biology, Ecology and Technology at Around of Tolandono Island and Sawa Island at Wakatobi Conservation Area. https://doi.org/10.31230/osf.io/4whz6

Nane, L. (2019d). Studi Keberlanjutan Perikanan Landak Laut Berdasarkan Dimensi Biologi, Ekologi Dan Teknologi Di Sekitar Pulau Tolandono Dan Pulausawa Kawasan Konservasiwakatobi [Skripsi, Universitas Hasanuddin]. https://Marxiv.Org/9zdvr/

Nane, L., \& Paramata, A. R. (2020). Impact of Overfishing on Density and Test-Diameter Size of the Sea Urchin Tripneustes gratilla at Wakatobi Archipelago, South-Eastern Sulawesi, Indonesia. ILMU KELAUTAN: Indonesian Journal of Marine Sciences, 25(2), 53-56. https://doi.org/10.14710/ik.ijms.25.2.53-56

Nane, L., Baruadi, A. S. R., \& Mardin, H. (2020). The density of the blue-black urchin Echinotrix diadema (Linnaeus, 1758) in TominiBay, Indonesia. Tomini Journal of Aquatic Science, 1(1), 16-21. https://doi.org/10.37905/tjas.v1i1.5939 
Nazar, M. (2017). Pola Distribusi Urchin (Echinodea) Pada Ekosistem Terumbu Karang (Coral Reefs) Di Perairan Ibaih Kecamatan Sukakarya Kota Sebang Penunjang Praktikum Ekologi Hewan (Doctoral dissertation. Uin Ar-Raniry Banda Aceh).

Rajab AW, Rumahenga SA, Soamole A, Polnaya D, Barends A.( 2014). Keragaman dan KepadatanEkinodermata di Perairan Teluk Weda, Maluku Utara. Jurnal IImu dan Teknologi Kelautan Tropis. 6(1):17-30.

Rajab, A.W., Khouw, A.S., Mosse, J.W., Uneputty, P.A.( 2010). Pengaruh Pemberian Pakan Terhadap Pertumbuhan dan Reproduksi Bulu babi (Tripneustes gratilla L) di Laboratorium.

Ristanto, A., Yanti, A. H., Setyawati,T. R., (2017). Komposisi Jenis Bulu Babi (Kelas: Echinoidea) Di Daerah Intertidal Pulau Lemukutan Kabupaten Bengkayang.

Rompis BR, Langoy MLD, Katili DY, Papu A. (2013). Diversitas Echinodermata di Pantai Meras Kecamatan Bunakan Sulawesi Utara. Jurnal Bioslogos. 3(1):26-31.

Silaban B. dan Srimariana E. (2013). Kandungan Nutrisi dan Pemanfaatan Gonad Bulu babi (Echinotrixs calamaris) dalam Pembuatan Kue bluder. Jurnal Pongolahan Hasil Perikan Indonesia. 6 (2): 108-118

Supono., Ucu, Y. A. (2012). Kelimpahan dan Keragaman Echino dermata di Pulau Pari, Kepulauan Seribu. Jurnal IImu dan Teknologi Kelautan Tropis. 4, 1: 114-120.

Suryati Dan Ruswahyuni , (2014). Perbedaan Kelimpahan Bulu Babi (Echinoidea) Pada Ekosistem Karang Dan Lamun Di Pancuran Belakang, Karimunjawa Jepara.

Suryanti dan C. A'in. (2013). Perbedaan Kelimpahan Bulu babi (Sea Urchin) pada Subtrat yang Berbeda di Legon Boyo Karimunjaya Jepara. Prosiding SEMNAS ke III. Hasilhasil Perikanan dan Kelautan. FPIK. UNDIP. Semarang. ISSN 2339-0833. 4:165172.

Susilo, V. E. (2017). Sebaran Local Echinodermata Di Pantai Bama Taman Nasional Baluran Bioedukasi, 14(2).

Thamrin, S., Yj. Siregar, SH. (2011). Analisis Kepadatan Bulu babi (Echinoidae) Diadema setosum pada Kondisi Terumbu Karang Berbeda di Desa Mapur Kepulaun Riau. IImu Lingkungan, Riau, 5(1):45-53.

Toha, A. H. A. (2019). Keragaman Genetik Bulu Babi (Echinoidea). Biota: Jurnal IImiah IImuIImu Hayati, 12(2), 131-135. 
Tupan,J. dan Silaban,B. (2017). Karakteristik Fisiki-Kimia Bulu Babi Diadema setosum. Uma, B. dan Parvathavarthini, R. (2010). Antibacterial Effect of Hexane Extract of Sea Urchin. International Journal of Pharm Tech Research, 2(3), 1677-1680.

Yudasmara Gede Ari, (2013). Keanekaragaman Dan Dominansi Komunitas Bulu Babi (Echinoidea) Di Perairan Pulau Menjangan Kawasan Taman Nasional Bali Barat. Issn: 2303-3142 Vol. 2, No. 2, Oktober 2013.

Yusron E. (2013). Biodiversitas fauna Ekhinodermata (Holoturoidae, Echinoidae, Asteroidae, dan Ophiuroidae) di Perairan Pulau Lombok, Nusa Tenggara Barat. Zoo Indonesia. 22(1):1-10.

Wulandewi, N. E., J. N. Subagio, dan J. Wiryanto.(2015). Jenis Dan Densitas Bulu Babi (Echinoidae) Di Kawasan Pantai Sanur Dan Serangan Denpasar-Bali. Jurnal Simbiosis III (1): 269- 280. ISSN: 2337-7224. 